\title{
Royal Marriage, Frankish History and Dynastic Crisis in Regino of Prüm's Chronicle
}

\author{
Eric J. Goldberg and Simon MacLean*
}

Regino of Prüm's Chronicle (907/908) is one of the most important works of contemporary history written in the era of the Carolingian Empire. In this article we consider Regino's numerous stories about good and bad royal marriages drawn from the deep past of the Franks, and we show how the historian adapted his source material to late Carolingian sensibilities. We then argue that Regino's interest in royal marriage can best be interpreted as a reflection of his anxiety about the marital status of the reigning East Frankish king Louis IV »the Child « (900-911). Regino dedicated his work to the king's godfather and counsellor Adalbero of Augsburg, and he apparently hoped to influence the king and his inner circle in the urgent task of selecting an appropriate royal bride. Regino's accounts of past rulers and their marital histories therefore give us an insight into how he perceived the political order of his own day and his fears about the future of the Carolingian dynasty.

Keywords: Carolingians; marriage; Regino of Prüm; historiography; Louis the Child; Lotharingia

\section{Introduction}

Regino of Prüm's Chronicle, composed in 907-908, offers a valuable case study in how the past could be used, and not used, in moments of crisis. The Chronicle was the last largescale Frankish history produced by the fertile historiographical culture of the Frankish Empire under the Carolingians. Written in two books from the birth of Christ to the year 906, it drew on numerous identifiable sources which Regino variously copied, abbreviated and altered. It was also written at a time of political disorder - the crisis of the empire itself, triggered by the death of Emperor Charles III »the Fat" in 888. This event marked the end of the Carolingian monopoly on royal power in the Frankish kingdoms that had endured since 751. It led to the accession of kings from various Frankish families, some (but not all) of whom were related to the Carolingians. This in turn led to a long period of doubt about the new dynastic dispensation that was characterised by political violence between kings, would-be kings and aristocrats. As Regino himself put it: »the equality of descent, authority and power increased the discord among [the new kings]; none so outshone the others that the rest deigned to submit to his rule. $\aleph^{1}$ The uncertainty and instability caused by the evaporation of the Carolingian

\footnotetext{
* Correspondence details: Eric J. Goldberg, History Department, MIT, 77 Massachusetts Avenue, Cambridge, MA 02139, United States; email: egoldber@mit.edu. Simon MacLean, School of History, University of St. Andrews, 71 South Street, St Andrews, Fife, KY16 9QW, United Kingdom; email: sm89@st-andrews.ac.uk. Regino, Chronicle, s.a. 888, ed. Kurze, 129, trans. MacLean, History and Politics, 199.
} 
royal monopoly provided the broad context for Regino's own life and work. His Chronicle, as Stuart Airlie has argued, can therefore be read not only as the last great Carolingian history but also as the first complete history of the empire's rise and fall, making Regino "the Edward Gibbon of Carolingian historical writing. $\Perp^{2}$

To judge by his appointment in 892 to the leadership of the monastery of Prüm in Lotharingia (the empire's "middle kingdom«), Regino himself was a well-connected figure. Prüm was one of the wealthiest and most prestigious monasteries in the empire, and it had enjoyed intimate connections with the Carolingian dynasty since its foundation in 721. As abbot of such an institution, Regino was inevitably drawn into high political circles, and at the end of the ninth century he was trusted enough by King Arnulf of East Francia (887-899) to be charged with the custody of the defeated Carolingian claimant Hugh of Lotharingia. ${ }^{3}$ Yet the abbot's foothold on the upper faces of Frankish political life was not secure, and in 899 he plummeted spectacularly when he was ejected from his monastery during a violent phase of the factional politics that blighted the middle kingdom after 888 . Thanks to the patronage of Archbishop Ratbod of Trier, who was a major player at the court of Arnulf's son and successor Louis IV »the Child « (900-911), Regino forged a second career as abbot of St-Martin in Trier, an altogether less prestigious posting than Prüm. Here, before his death in 915, he composed the three scholarly works for which he is best remembered today: a treatise on music, a collection of canon law intended to inform episcopal visitations, and the Chronicle. ${ }^{4}$

The latter has attracted much attention in recent years, and its second book (which runs from 741 to 906 and becomes an independent account after 818) is familiar to historians as one of the most important narrative sources for the second half of the ninth century. Regino's first book, which begins with the Incarnation of Christ and runs through to the death of the proto-Carolingian mayor of the palace Charles Martel in 741, has received much less attention. ${ }^{5}$ This section of the Chronicle is made up of a patchwork of citations from several earlier works (including Paul the Deacon's History of the Lombards, Bede's Greater Chronicle and the anonymous Deeds of Dagobert) and has sometimes been dismissed as a work of cut-andpaste plagiarism. But Regino was an innovative historian (he was one of the first chroniclers to begin with the Incarnation and attempt a coherent AD chronology), and we should not forget that the act of selection and compilation can itself articulate an authorial voice. One of the aims of this article is to identify some of the ways that Regino actively used this more distant past to offer implicit commentary on his present.

2 Airlie, »Sad stories«, 126.

3 Regino, Chronicle, s.a. 885, ed. Kurze, 125.

4 For accounts of Regino's career and work, see Hüschen, Regino; Hlawitschka, Regino; MacLean, History and Politics, 1-53.

5 Though see von den Brincken, Studien zur lateinischen Weltchronik, 128-133; McKitterick, Perceptions of the Past, 30-33, 38-42. 
What was the purpose of the Chronicle? We need not look for a single answer to this question. To some extent history was a self-justifying genre for Carolingian intellectuals: for Regino, as a scholar and monastic leader, participation in the culture of history-writing, which was such an important part of contemporary learned discourse, needed no explanation beyond itself. ${ }^{6}$ Undoubtedly, Regino wanted to demonstrate the influence of God and the saints in the world, and celebrate the triumph of the church. ${ }^{7}$ His account of the rise and fall of the Frankish Empire therefore can be read as an object lesson in the fleeting nature of earthly power and the ultimate victory of divine justice. ${ }^{8}$ These historiographical ambitions in the design of the work did not, however, prevent Regino from communicating more immediate messages to his readers. His closing pages betray an autobiographical impulse, as the abbot lamented his ejection from Prüm and justified his own behaviour in the events that led to his downfall. ${ }^{9}$ Regino's hoped-for audience included Bishop Adalbero of Augsburg, to whom he dedicated the Chronicle. History was sometimes written as advice literature for kings, and it is significant that Adalbero was one of the guardians of the teenaged Louis the Child. Indeed, Louis's charters refer affectionately to the bishop as his "nutritor " (fosterfather/godfather) and "magister" (teacher). ${ }^{10}$ By dedicating his Chronicle to Louis's teacher and counsellor, Regino undoubtedly hoped it would be read and studied by the king himself.

It has been suggested that the Chronicle would not have worked as advice for a ruler because it does not contain a consistently organised catalogue of military or kingly examples for emulation. ${ }^{11}$ However, there is at least one theme that runs consistently through the narrative: royal marriage. Regino's interest in this subject is not surprising since his work was concerned with the histories of dynasties. Yet the Chronicle gives much more coverage to royal marriages than most other Carolingian narratives. Regino's expertise in this area is clear from the extensive coverage of marriage law in De synodalibus causis, his handbook of legal authorities intended to inform the diocesan work of bishops. This was written around the same time as the Chronicle. It had been commissioned by another of Louis the Child's guardians, Archbishop Ratbod of Trier, and c. 906 it was dedicated to a third, Archbishop Hatto of Mainz. ${ }^{12}$ As Karl Ubl has shown, Regino's meticulous organisation of his sources on marriage law was not neutral. Instead, he articulated a distinctive and nuanced position that was deeply informed by Roman, papal and Carolingian legislation on the subject. ${ }^{13}$

6 McKitterick, History and Memory.

7 Meens, Rise and fall; Bohnenkamp, Regino.

8 Airlie, "Sad stories«.

9 MacLean, Insinuation.

10 Schieffer (ed.), Die Urkunden Ludwigs, nos. 4, 9, 65, 66. Chronicle as advice: e.g. MacLean, History and Politics, 1718.

11 Ubl, Doppelmoral, 124.

12 Regino, De synodalibus causis.

13 Ubl, Doppelmoral. 
Regino's cataloguing of all kinds of royal unions in the Chronicle therefore deserves close examination and careful analysis. In the remainder of this article, we will discuss the various ways that he presented the history of royal marriages to his hoped-for readers. By considering the ways in which Regino adapted and arranged his sources, we can shed new light on how the abbot organised and manipulated the historical past to address the discourses and debates of his own day. We will argue that the prevalence of royal marriages in the Chronicle must be understood in the context of the political crisis Regino was living through and his mounting concerns about the future of the Carolingian dynasty. There is reason to believe that Regino intended his gallery of good and bad royal marriages to serve as a guide for Louis the Child's guardians in one of the most pressing political questions of the day: the selection of a suitable bride for the unmarried East Frankish king. The tumultuous events of the year 907 were, as we shall see, crucial in bringing this issue to the forefront of Regino's thinking. Only through an acceptable Christian marriage, Regino suggested, could the now adult Louis produce a male heir who might rescue the foundering Carolingian family and bring security to the contested territory of Lotharingia, in which the abbot's own tumultuous career played out.

\section{Regino's Queens}

The centrality of the Carolingian royal dynasty to Regino's narrative makes it easy to take for granted the frequent appearance of queens and marriages. Often they are mentioned so casually that their symbolism is easily missed, as in the regular obituaries which praise good kings for the nobility of their wives and the legitimacy of their marriages and children. ${ }^{14}$ This insistence on legitimacy must be understood in light of Regino's obvious fascination with the divorce case of Lothar II (855-869). This notorious dispute revolved around Lothar's attempts to divorce his wife Theutberga and return to an earlier union with Waldrada, the mother of his son Hugh. Debates over the solubility or otherwise of his marriage to Theutberga were played out against a menacing political backdrop, with the opposition of his uncles Charles the Bald and Louis the German, and of Pope Nicholas I, making it impossible for Lothar to gain sanction for his plans before the pope's death in 867. Nicholas's successor Hadrian II was apparently happy to absolve Lothar of his sins during a trip to Rome in 869 , but the taste of victory was still fresh in the king's mouth when he fell ill and died before reaching the Alps. ${ }^{15}$ Regino was not the only author to savour this outcome as a manifestation of divine judgement. He was, however, alone in seeing Lothar's actions as the epicentre of an historical earthquake that would ultimately lead to the fall of his kingdom. Regino alerts the reader to this outcome in the same breath as he reports the marriage itself: "The greatest ruin resulted from this union, not only for him, but also for his whole kingdom «. Later, he delivers the pay-off in his account of the violent rebellion mounted by Lothar's son in 883: "Thus almighty God was enraged at the kingdom of Lothar, and He began to act against and utterly destroy the strength of that same kingdom by increasing disasters of such a kind that the prophecy of the most holy Pope Nicholas, and also the curse which he had pronounced over this kingdom, was fulfilled. ${ }^{16}$ 
The disasters to which Regino referred included those that wracked Lotharingia, the kingdom of Lothar II where the abbot's own personal tragedies played out in the 890s. Yet within the structure of Regino's narrative, they also had consequences for the Carolingian family as a whole. Later in the text, Regino blamed the dwindling of the Carolingian line on two main factors: "the delicate youth of those kings who died «, and »the sterility of their wives. « $^{17}$ He saw these dynastic hardships not as mere bad luck, but as further symptoms of divine displeasure. Quoted in the Chronicle, Pope Nicholas I had mused upon the significance of sterility in one of his letters to Lothar: "perhaps this sterility is not caused by infertility but by unrighteousness ${ }^{18}{ }^{18}$ In the Chronicle, then, Regino presented the sterility of Lothar's marriage and the "increasing disasters" that engulfed his realm as part of - indeed, perhaps the source of - the tragedy of the whole Carolingian dynasty.

Regino's carefully crafted narrative is the handiwork of a canon law connoisseur. The case of Lothar II was (in its own time and in Regino's retelling) a dispute both about ecclesiastical jurisdiction and about the status of the king's marriage to Waldrada. Extensive (though often contradictory) early medieval legislation addressed marital legitimacy and questions of jurisdiction, and Regino collected numerous texts on both in his episcopal handbook. ${ }^{19}$ This much is fairly obvious to even a casual reader of the Chronicle, whose stance on the Lothar case is nothing if not clear. How, then, did his approach to other Carolingian marriages compare?

The case of Louis the Stammerer, king of West Francia (877-879) who was separated and remarried, was potentially as incendiary as that of Lothar II, since each wife produced male heirs. According to the mainstream papal line, which Regino usually endorsed, divorce was generally not allowed except in exceptional circumstances: as Nicholas I announced, he would endorse Lothar's separation only if both spouses agreed to take up monastic vocations. ${ }^{20}$ Louis the Stammerer and his first two sons died young (in 877, 882, and 884, respectively), before the son by his second wife (Charles III "the Simple") reached adulthood (in 894). By the time Regino was writing, this Charles was king of West Francia and arguably the most powerful ruler in Europe. Regino presumably knew him personally, since Charles had visited Prüm with his army during his failed attempt to annex Lotharingia in $898 .{ }^{21}$ Charles was a powerful and intimidating figure in Regino's world at the time he was writing, and the West Frankish king continued to have political connections in, and aspirations one day to rule, the middle kingdom.

Regino therefore needed to tread lightly in his account of Louis the Stammerer's complex marital history, since it was dangerous to challenge openly the legitimacy of Charles's birth. In his telling, it was Louis's father Charles the Bald who forced him to abandon his first wife Ansgard (because Louis had "admitted her to his embraces without the knowledge or consent of his father") and subsequently "gave him [Charles the Simple's mother] Adelaide in 
matrimony «. ${ }^{22}$ Some Carolingian writers including Hincmar of Rheims viewed the consent of betrothed parties' families as an essential part of the nuptial process and thus as an indispensable component of legitimate marriage. ${ }^{23}$ Whether Regino held this view in this case is questionable, however, since Lothar II's supporters had used the very same arguments to legitimate that king's divorce from Theutberga and reunion with Waldrada. ${ }^{24}$ Regino's thinking was perhaps more in line with that of Pope John VIII, who was reluctant to crown Adelaide on the grounds of the prohibition against divorce. ${ }^{25}$ As we will see, Regino's political allegiances to Louis the Child led him to paint a subtly negative picture of Charles the Simple. Nevertheless, apparently because of ongoing concerns about Charles the Simple's influence in Lotharingia, Regino did not openly approve or condemn the legitimacy of Louis the Stammerer's union with Charles's mother. Here one detects how contemporary political concerns shaped what Regino could say about one particularly knotty royal marriage.

Regino's account of Charles the Fat's divorce in 887 further illustrates the flexibility of his attitude toward royal marriage. In contrast to the way he had dealt with Lothar II's divorce, Regino's report of Charles the Fat's is remarkably unquestioning. The Chronicle describes how Charles expelled his chief adviser Liutward of Vercelli on suspicion of adultery with Empress Richgard, who then publicly announced that she was a virgin and, after this was confirmed by an ordeal and by Charles himself, retired to a nunnery she had founded. ${ }^{26}$ Lying behind this implausibly straightforward tale was a somewhat contentious attempt by the emperor to remarry in order to produce an acceptably legitimate heir. ${ }^{27}$ Regino's willingness to absolve Charles from criticism partly follows from the high regard in which he evidently held the king, whose exemplary piety and Christian endurance he praised lavishly. ${ }^{28}$ As we will see, it also reflected his desire to honour Louis the Child's ancestors, the East Frankish Carolingians.

The idea that non-consummation could be grounds for annulment (or, more precisely, grounds for having a union recognised as a non-marriage) was put most forcefully by Hincmar of Rheims in his pronouncements on the case of Count Stephen of Toulouse in $860 .{ }^{29}$ But some councils of the earlier, more permissive, phase of Carolingian reform had ruled along similar lines, notably the councils of Verberie in 756 and Compiègne in 757. The former, excerpted by Regino in De synodalibus causis, includes a clause that corresponds very

22 Regino, Chronicle, s.a. 878, ed. Kurze, 114. Charles's interest in controlling his children's marriages was obviously political, particularly as Louis had first taken up with Ansgard during a period of rebellion in 862: Annales Bertiniani, s.a. 862, ed. Grat et al., 91. In fact, it is likely that Louis the Stammerer's second marriage was effected, like the first, autonomously: Brühl, Hinkmariana II; McNamara and Wemple, Marriage and divorce, 112 and n. 134. On Regino and Charles the Simple, see MacLean, Insinuation.

23 Reynolds, Marriage, 401-412; Toubert, Carolingian moment, 399.

24 Lothar II's supporter Bishop Adventius of Metz had argued that the role of Lothar's father in brokering the earlier union with Waldrada was fundamental proof of its legitimacy: Heidecker, Why should bishops, 234-235. Regino's main source of information on the Lothar case was a dossier of texts created by Adventius of Metz: Staubach, Herrscherbild, 153-214; West, Knowledge of the past. 
closely to the process described in the 887 case: if a woman publicly declares that her husband has never had sex with her and successfully proves this by means of an ordeal, then they can separate and she can do as she wishes. ${ }^{30}$ One wonders if Regino also had in mind the parallel story of the famous seventh-century Northumbrian queen Æthelthryth, whose career closely resembled what Regino says about Richgard's: a chaste marriage followed by retirement to a self-founded nunnery. Regino did mention Æthelthryth, »queen and virgin«, in Book I, which was a very rare notice of insular affairs. Indeed, Regino's statement that Richgard and Charles had been married for more than ten years (when in fact it had been more like twenty-five) is notably similar to what Bede said about Æthelthryth. ${ }^{31}$

As Regino very well knew, there were also strong arguments against such a view: this interpretation of non-consummation represented a slender thread in Carolingian legislation, the bulk of which weighed heavily against the validity of this kind of separation. In deploying canonical concepts in his descriptions of Carolingian marital disputes, Regino adopted the persona of the advocate rather than that of the judge. The key point to emphasise is that his accounts of Carolingian disputes stayed well within the categories of mainstream thinking on marital legitimacy, but they did not articulate a consistent position on marriage per se. Rather, they served the various themes of his Chronicle: to underline the exemplary holiness of Charles the Fat, to imply doubt about the legitimacy of Charles the Simple, and to call attention to the divine judgement brought on the Carolingians by the behaviour of Lothar II. Similarly, Regino described the mother of Louis the Younger's son using the derogatory terms "concubine" (as he had for Waldrada); but the mother of Arnulf (who was equally unmarried) as »a certain noble woman. $\aleph^{32}$ The double standard here was surely due to the fact that Arnulf was the father of the king for whose inner circle Regino was writing: Louis the Child. The abbot's use of legalistic concepts and categories was therefore an important component of his rhetorical machinery. As a scholar of canon law, he appreciated more than most the variety of overlapping interpretations of marital legitimacy, but that does not mean that he thought legitimacy was an unimportant or elusive category. Regino manipulated the rules of marriage not by ignoring them, nor by slavishly following canonical authorities, but by deciding which to apply or emphasise.

Regino did not limit to the Carolingian dynasty his use of marital legitimacy to convey judgements about particular rulers. In parts of Book I, he anachronistically superimposed Carolingian perspectives on marriage onto the pre-Carolingian past. The Chronicle's very first entry shows Regino's editorial hand at work. Here, Regino quotes and paraphrases Bede's Greater Chronicle to tell the story of King Herod turning on his own family, first killing his wife Mariamne and her sons, and then slaying his son Antipater by his former lover Dosis. ${ }^{33}$ Here Regino subtly reordered Bede's material and inserted the additional comment that Antipater "had been the inciter of all these evil things". By doing so, he reshaped this famous story in a Lothar II-like mould and highlighted from the outset the danger of

30 Regino, De synodalibus causis, 2.244, ed. Hartmann, 362-363 (cf. also nos. 243 and 245).

31 Regino, Chronicle, s.a. 605-611, ed. Kurze, 31-32, trans. MacLean, History and Politics, 108; Bede, De Temporum Ratione, ed. Jones, 528-529.

32 Regino, Chronicle, s.a. 879, 880, ed. Kurze, 115-116, trans. MacLean, History and Politics, 181-182. See McDougall, Royal Bastards, 66-93.

33 Regino, Chronicle, s.a. 1-15, ed. Kurze, 2; trans. MacLean, History and Politics, 63; Bede, De Temporum Ratione, ed. Jones, 494. 
»illegitimate spouses and sons for the politics of the realm. ${ }^{34}$ Herod was remembered in the early Middle Ages as an archetypally bad king emblematic of rulers who had incurred God's displeasure..$^{35}$ This ominous adumbration of the 860 s projected back on the nefarious king of Judea warned the reader that illicit unions and illegitimate sons had been a cause of political hardship and turmoil throughout Christian history.

Regino also shows interest in the marriages of the first Frankish royal dynasty, the Merovingians. Dynasty and people step together onto the Chronicle's historical stage with the baptism of their first Christian king Clovis »together with the Franks" in a year reckoned by Regino to be between 421 and $449 .{ }^{36}$ This passage illuminates an important feature of Regino's overall narrative in that here he implicitly rejected the Frankish origin myth found in one of his main sources, the early eighth-century Neustrian work known as the Liber Historiae Francorum ( $L H F$, "Book of the History of the Franks«). Instead, he (like Gregory of Tours) implanted the Franks in a broader Christian narrative about progress towards universal conversion. ${ }^{37}$

This section of the Chronicle draws primarily on the LHF and on Paul the Deacon's late eighth-century History of the Lombards, both of which furnished Regino with plenty of information on the early Merovingians. He was initially content to stick close to this material, summarising as he went, but his narrative becomes more expansive, and shows clearer signs of editorial intervention, after the reign of Clovis. Take, for example, his account of Clothar I, who became king in 511 and was sole ruler of the Franks from 558 until his death in 561. After describing the division of Clothar's kingdom between his four sons, Regino moves on to offer evaluations of each of the sons' reigns, laying particular emphasis on the nature of their marriages. Though he seemingly approved of Sigibert's union with the Visigothic princess Brunhild, Regino thought differently of Charibert, who "abandoned his legitimate wife, who was called Ingoberga, and took in marriage the two sisters Marcovefa and Merofilda. On account of this abominable act he was excommunicated by St Germanus, the bishop of Paris, and, struck down by the just judgement of God, died. « $^{38}$ Regino fortifies the vocabulary of his source, the LHF: "legitima uxor" (legitimate wife) and "scelus" (abominable act) are his words, and they echo the furious debate surrounding Lothar II's divorce. These changes subtly shift the emphasis of the original. While the $L H F$ suggests the king was punished for marrying two sisters in turn (a form of incest also prohibited in the legislation of Regino's day), the Chronicle's selective emphasis and vocabulary shift the weight of disapproval onto the divorce ${ }^{39}$ Regino drives his point home with a punchline not found in his sources: "Sigibert seized his kingdom «. He no doubt inferred this outcome from information found later in the $L H F$, but his emphatic ordering implied that the triumph of Sigibert (of whose own marriage Regino approved) was the result of God's judgement on Charibert's personal life.

\footnotetext{
34 For Lothar's son Hugh, see Regino, Chronicle, s.a. 883, ed. Kurze, 120-121.

35 Halsall, Nero and Herod.

36 Regino, Chronicle, s.a. 421-449, ed. Kurze, 19-20. The real date was nearer 500: on Regino's chronological errors see Sonntag, Studien, 87-120; MacLean, History and Politics, 20-3.

37 MacLean, History and Politics, 25-26; Reimitz, History, 44-60.

38 Regino, Chronicle, s.a. 498-509, ed. Kurze, 22, trans. MacLean, History and Politics, 91; Liber Historiae Francorum, cc. 30-1, ed. Krusch, 290-291.

39 On incest see now Ubl, Inzestverbot.
} 
Of the four brothers, Regino depicted Chilperic as having had the most colourful marital career. Chilperic's first two wives were Brunhild's sister Galswinth and Queen Audovera, by whom he had three sons. He killed the first wife and abandoned the second on the urging of the woman who would become his third, Fredegund. ${ }^{40}$ Fredegund was one of Frankish history's archetypally wicked queens, and Regino, faithful to his sources, describes her evil influence on Chilperic in some detail. However, he notably modifies his source material concerning Chilperic and Fredegund's children, apparently because he wished to praise their son Clothar II, who fathered one of Regino's heroes, Dagobert I. The LHF makes clear that Chilperic and Fredegund had other sons before Clothar II, several of whom died in a divinelyordained plague that struck after Chilperic, at Fredegund's prompting, levied unjust taxes on his subjects. However, Regino leaves uncertain the identity of the mother of Chilperic's sons who died in the plague, and he makes it seem as if his first son by Fredegund was Clothar II, who was born after the plague: "After [abolishing the taxes] he had intercourse with his wife, who bore him a son whom he called Clothar [II]. He was later a great king who was the father of Dagobert. ${ }^{41}$ In view of his keenness to signal approval for Dagobert, it seems that Regino placed here this unusually explicit reference to sexual intercourse to imply that Clothar II had been conceived right after an unusual episode of penance for the otherwise wicked Chilperic and Fredegund. Perhaps he even wanted to imply that they had not consummated their marriage, and thus in his eyes formalised it, until that point. The organisation of the passage shows Regino working to associate the genesis of this particular line of Merovingian kings with a moment of divine approval for its progenitor.

Regino's account of this generation of Merovingians therefore shows signs of significant editorial intervention. Although he actively reworded his sources only rarely, he altered their emphasis - and thereby created an individual text - through decisions about inclusion, omission, abridgement and chronological order. In general, Regino exchanged the LHF's moral messages about the dangers of fraternal discord and the problems presented by Arian wives for a series of judgements that evaluated rulers' fates according to the propriety of their marriages. Thus, Sigibert and Brunhild's marriage, discussed first, was used to provide a positive example against which his brothers' irregular affairs could be set.

What attitudes to politics, history and law underlay this editorial policy? One possibility is that Regino was simply updating Merovingian history to fit Carolingian norms. This might explain his account of Sigibert's grandsons Theudebert and Theuderic fighting over the kingdom because Theudebert is said to have been born to a concubine. Where the LHF says Theudebert was killed and his head mounted on the walls of Cologne, Regino has him tonsured and committed to a monastery..$^{42}$ To a Carolingian author, this was a more fitting fate for illegitimate royals, and one that had specific resonance for Regino, who himself had been responsible for the tonsuring and imprisonment of Lothar II's son Hugh at Prüm. ${ }^{43}$ Other omissions also hint at a modernisation of norms: leaving out the $L H F$ 's praise for Sigibert's

40 Regino, Chronicle, s.a. 498-509, ed. Kurze, 22.

41 Regino, Chronicle, s.a. 510-516, ed. Kurze, 24; trans. MacLean, History and Politics, 94; Liber Historiae Francorum, cc. 34-35, ed. Krusch, 299-304. For "cognoscere» in the sense of "to have sex with", see Regino, De synodalibus causis, 2.150, ed. Hartmann, 318-319.

42 Regino, Chronicle, s.a. 538-545, ed. Kurze, 27; Liber Historiae Francorum, c. 38, ed. Krusch, 307-309.

43 Regino, Chronicle, s.a. 885, ed. Kurze, 125. 
marriage to a foreign princess rather than a social inferior was a diplomatic move in a text intended for a Carolingian court, since marriage to Frankish aristocrats (social inferiors) rather than members of other royal families was standard Carolingian practice. ${ }^{44}$

Given Regino's specialist interest in canon law, one might reasonably imagine that a legal sensibility informed Regino's interest in marital propriety. This could explain the surprisingly lukewarm account he gives of Constantine the Great and his mother Helena, whose most celebrated achievements (organising the Council of Nicaea and discovering the True Cross, respectively) are shunted exclusively onto Pope Sylvester and Judas Cyriacus. This is somewhat incongruous since Helena was recognised as a saint and credited with the "invention" of the Cross in other Prüm texts (including Regino's own tract on music), and the abbot's downplaying of the imperial initiative in the Chronicle is out of step with the emphasis of his sources. It was apparently in response to this incongruity that Adalbert of Magdeburg, Regino's continuator and editor, felt compelled to enter here the corrective that under Constantine: "peace was restored to the churches, bishops deprived of their sees were restored, and many other things were conceded that were useful to the Christian religion." It is not obvious why Regino skewed his sources in this way unless we take seriously his description of Constantine (drawn from Bede) as "son of Constantius by his concubine Helena «. ${ }^{45}$

If Regino's goal in the Chronicle were to present a historicised exposition of consistent legal principles, it is hard to understand why he whitewashed the notoriously Lothar IIesque marital affairs of Dagobert I; and why he omitted the $L H F$ 's comment on the marriage of Merovech, Chilperic's son, to his uncle's widow Brunhild, "against divine command and canon law. ${ }^{46}$ Regino's history certainly demonstrates that he had a strong interest in matters of marital legitimacy and its relationship to political legitimacy; and, as in De synodalibus causis, he showed himself to be a connoisseur of the overlapping and sometimes competing streams of Carolingian thought on marriage, and broadly sympathetic to the relatively hardline position taken by Nicholas I during the Lothar dispute. Nonetheless, he did not apply a single interpretation dogmatically or even consistently in his Chronicle. Instead, he used the lexicon of marriage as a proxy for judgement on the behaviour of kings he saw as good or bad; and presented a gallery of good and bad marriages (including many more not mentioned above), with variously good and bad consequences for the kings who made them. In the next section we will ask how Regino's interest in the colourful history of royal marriage can be best understood in the political context prevailing at the time he was writing.

44 Regino, Chronicle, s.a. 498-509, ed. Kurze, 22; Liber Historiae Francorum, c. 31, ed. Krusch, 291.

45 For this paragraph see Regino, Chronicle, s.a. 263-294, ed. Kurze, 14-15; trans. MacLean, History and Politics, 7879. On Helena's standing at Carolingian Prüm see Haubrichs, Kultur der Abtei Prüm, 164, 168.

46 Dagobert: Regino, Chronicle, s.a. 605-611, ed. Kurze, 31-32; here silently emending Gesta Dagoberti, cc. 22-24, ed. Krusch, 408-409. Merovech: Regino, Chronicle, s.a. 498-509, ed. Kurze, 22; Liber Historiae Francorum, c. 33, ed. Krusch, 298: "contra fas et legem canonicam." 


\section{Past, Present and Future in Regino's Marital History}

When considering Regino's thinking, it should not be forgotten that the unions whose histories he narrated were royal marriages, and that as a historian (and a member of the ruling class) he had a strong interest in the dynastic politics that ran alongside his canonist's interest in marital law. In a dynastic political system like that of the Franks, royal marriage shaped the political order. Its history was therefore not an inert aspect of the past, but rather a force that shaped the future. Sara McDougall is surely correct to argue that »the canon law of marriage did not function as a bright line rule that classified Carolingian sons as throneworthy or not «. ${ }^{47}$ Canon law in all its variety was a resource that writers like Regino could use (or not use) in their construction of arguments about the unfolding of dynastic history. Regino's choices therefore need to be understood not only as expressions of his intellectual preoccupations, nor as simple reflections of the power or consistency of contemporary canon law, but also as arguments formed in the context of the complex political situation at the time he was writing. In the rest of this article we will suggest that Regino's interest in the history of Frankish royal marriages was partisan, and should be interpreted as a response to the specific dynastic situation in which he was personally invested. In particular, Regino was deeply worried about the future of King Louis the Child and the continuation of his east Frankish Carolingian line.

That Regino himself made a connection between legitimate marriage and political legitimacy is suggested by his account of the reign of Theudebert II, who "was said not to be the legitimate heir of the kingdom because he had been born to a concubine." This was another occasion on which Regino shifted the emphasis of his source, the $L H F$, from the adultery of Theudebert's father to the fact that his mother was not his father's legitimate wife..$^{48}$ The connection between marital and political legitimacy was explored at much more length in the "Revelation of Pope Stephen «, which Regino inserted into his otherwise faithful reiteration of the "Royal Frankish Annals" in the section of the Chronicle covering the second half of the eighth century. This text legitimised the advent of Carolingian rule in the early 750 s by emphasising apostolic approval for their takeover. According to the text, Pope Stephen told the Franks to regard only the descendants of Pippin and Bertrada (the first Carolingian king and queen) as legitimate rulers, and not "ever to presume in any way to make a king over them from any family other than the descendants of that one which divine providence had seen fit to choose to protect the apostolic see and...to raise to royal power and to consecrate with the most sacred unction. « ${ }^{49}$ In this way, Regino placed at the heart of his Chronicle the solemn papal injunction that the Franks should select their kings only from the Carolingian family in direct descent from the original royal couple.

Re-narrating this probably fictional story (which was written at St-Denis in the 830s) served one of Regino's main agendas, namely to underline the significance of the papacy to the legitimacy of the royal political order. ${ }^{50}$ But it also drew attention to the political landscape of his own age, which was defined by the very fact that most of the Frankish kingdoms had

47 McDougall, Royal Bastards, 93.

48 Regino, Chronicle, s.a. 538-545, ed. Kurze, 27 (»quia de pelice erat natus«); trans. MacLean, History and Politics, 100; LHF c.38, ed. Krusch, 307-308 ("quia in adulterio in concubina patris ... procratus fuit").

49 Regino, Chronicle, s.a. 753, ed. Kurze, 45; trans. MacLean, History and Politics, 128.

50 For this text and its date, see Stoclet, La Clausula. 
been ruled by non-Carolingians since 888 , after a series of unexpected royal deaths left the dynasty without viable male heirs. The most detailed account of this shift is in fact the one found in Regino's Chronicle, which highlighted how the new kings' inability to claim seniority of lineage over each other led to tension and conflict between them. ${ }^{51}$ The post- 888 political order was in flagrant violation of Pope Stephen's injunction. The Chronicle has therefore been read as an ironic history of the Carolingians, with their triumphant rise always overshadowed by the audience's foreknowledge of their fall in $888 . .^{52}$

We should pause, however, before interpreting Regino's ironic perspective as intended to draw a definitive end to the story of the Carolingians. ${ }^{53} \mathrm{He}$ was, after all, writing for the closest advisers of the East Frankish king, Louis the Child, who was indeed a direct male-line descendant of Pippin and Bertrada. Louis's father Arnulf was born illegitimate, and for that reason had not been recognised as a superior ruler by the other new kings in 888 . Writing with two decades of hindsight, Regino made a special plea for Arnulf and Louis as the authentic continuers of the Carolingian line. After all, Regino asked in his preface for Adalbero's approval for what he had written, suggesting a desire that his version of history should be aligned with the way it was seen by the inner circle at court. ${ }^{54}$ Thus in the 888 entry itself, he implies that Arnulf ought to have been obeyed by the other kings as their "natural lord". In another entry where he laments the dwindling of the Carolingian line, Regino again suggests that Arnulf was the one legitimate king able to continue the dynasty: "he alone" ("hic solus") was found suitable to take up the sceptre of the realm of the Franks. ${ }^{55}$ In the same section, Regino pointedly claims that Arnulf's father had named him after Bishop Arnulf of Metz (d. 640), the sainted founder of the Carolingian dynasty itself, thus signalling that King Arnulf was the renewer or re-founder of the line after its crisis in $888 .{ }^{56}$ This impression is strengthened by the prominence Regino gives earlier in the Chronicle to Arnulf of Metz himself, in his capacity as mayor of the palace to Clothar II and tutor to his young heir Dagobert I. ${ }^{57}$ Regino somewhat idealizes Dagobert as a proto-Carolingian, brought up under Arnulf's influence, and he omits his reputation for marital misbehaviour. At the same time, his emphasis on Dagobert's upbringing by a wise bishop was a nod to Regino's own dedicatee Adalbero of Augsburg and his role as the guardian of Louis the Child.

One especially sees Regino's partisanship toward Louis the Child in his praise for Louis's ancestors, the East Frankish branch of the Carolingians. It is true that Regino praises nonEast Frankish rulers such as Louis II of Italy and even the usurper Boso of Provence. ${ }^{58}$ Nevertheless, he chiefly acclaims the piety, military prowess, and physical beauty of Louis the Child's direct forebears: his father Arnulf, his grandfather Karlmann, his great uncles Louis the Younger and Charles the Fat, and above all, his great-grandfather Louis the German

51 Regino, Chronicle, s.a. 888, ed. Kurze, 128-129.

52 Airlie, »Sad stories«.

53 In contrast: MacLean, History and Politics, 42-43; MacLean, Insinuation, 17-18.

54 Regino, Chronicle, preface, ed. Kurze, 1.

55 Regino, Chronicle, s.a. 880, ed. Kurze, 116-117, trans. MacLean, History and Politics, 183.

56 Becher, Arnulf.

57 Regino, Chronicle, s.a. 546-571, 605-611, ed. Kurze, 28, 31.

58 Regino, Chronicle, s.a. 874, 879, ed. Kurze, 107, 114-15. 
(840-876), the founder of the East Frankish Carolingian branch. ${ }^{59}$ Regino's account of this first East Frankish king stands out as the most laudatory royal portrait in the entire Chronicle, surpassing even those of Dagobert and Charlemagne. He repeatedly praises Louis the German, »the most Christian king who exercised imperial rule over the Germans«: for rescuing his father Louis the Pious during the rebellion of $833 / 834$, for his numerous triumphs over the Slavs, for his efforts to Christianize the Bulgars, for his kindness and mercy toward his relatives, and for his heroic toughness and courage in the face of adversity. ${ }^{60}$ Regino then brings together all the royal virtues found throughout the Chronicle - piety, education, political talent, military skill, a good marriage - in his eulogizing epitaph for Louis the German, which he obviously intended as a model for his great-grandson. ${ }^{61}$

Regino's selection of the first East Frankish king as a model for Louis the Child was not by chance: when Hatto of Mainz and Adalbero of Augsburg baptized the infant Louis the Child in 893, they explicitly named him after his great-grandfather. ${ }^{62}$ Arnulf and his circle of counsellors thus hoped Louis the Child would revive the fortunes of the East Frankish kingdom as it had thrived under Louis the German. The fact that Louis the Child authenticated his diplomas with Louis the German's royal seal made visible his identification with his famous great-grandfather. Louis the German's seal was probably one of the pieces of East Frankish regalia ("regia ornamenta") that, according to Regino, Louis the Child received during his coronation in 900: "The magnates and leading men who had obeyed Arnulf gathered together as one at Forchheim and made Louis, the son by legitimate marriage of the abovementioned prince, their king. After he was crowned and adorned with the royal trappings, they raised him to the pinnacle of the kingdom. ${ }^{63}$ Regino's emphasis on the ancestral royal trappings as well as the coronation highlight his belief in Louis's identity as the rightful heir to the Carolingian dynasty.

Regino's pointed remark that Louis the Child was Arnulf's "son by legitimate marriage" calls attention to a key theme that runs throughout his positive depictions of the East Frankish Carolingians: the quality of their marriages. Regino concludes his eulogy for Louis the German with an encomium to his noble and fertile wife, Queen Emma, who bore him »three sons of most excellent character«, Karlmann, Louis the Younger, and Charles the Fat, »who

59 Regino, Chronicle, s.a. 876 (Louis the Younger's valour, resembles his father in intelligence and cleverness), 880 (eulogy for Karlmann, Arnulf's noble mother, name, and beauty), 881 (Louis the Younger convinces Vikings to leave kingdom), 882 (Louis the Younger's legitimate marriage), 888 (eulogy for Charles the Fat), 891 (Arnulf's victory over the Vikings at the River Dyle), ed. Kurze, 112, 116-119, 128-129, 137-138.

60 Regino, Chronicle, s.a. 838 (rescues Louis the Pious), 860 (victorious wars against Slavs), 868 (support in converting Bulgars), 870 (toughness and courage when injured, mercy toward his blinded nephew), ed. Kurze, 74, 78, 95, 100-102. Regino's sole criticism of Louis the German was for his invasion of West Francia in 858: Regino, Chronicle, s.a. 866, ed. Kurze, 90. This is understandable, since Regino worried about the perils of civil war among rival kings (as he had experienced first-hand in Lotharingia) and advocated territorial expansion through peaceful diplomacy and the laws of inheritance.

61 Regino, Chronicle, s.a. 876, ed. Kurze, 110-111. For the reign of Louis the German, see Goldberg, Struggle for Empire.

62 Annales Fuldenses (Regensburg continuation), s.a. 893, ed. Kurze, 122: "quem [Louis the Child] Haddo Magonciacensis archiepiscopus et Adalpero Augustae Videlicae episcopus sacro fonte baptismatis chrismantes nomine avi sui [i.e., the name of Arnulf's grandfather] Hludawicum appellaverunt."

63 Regino, Chronicle, s.a. 900, ed. Kurze, 147-148, trans. MacLean, History and Politics, 225. On this passage, which is the first explicit report of a »German « coronation, see Schramm, Salbung und Krönung, 287-302. Concerning Louis the Child's use of Louis the German's seal, see Schieffer (ed.), Die Urkunden Ludwigs, 92-93. Louis the Younger likewise had used his father's seal. 
by happy destiny managed the government of the empire after their father's death « ${ }^{64} \mathrm{He}$ goes on to portray the unions of Louis the German's successors in a positive light, although this required considerable massaging of the messy truth. ${ }^{65}$ For example, Regino bends over backwards to explain away the problem of Arnulf's illegitimacy: he assures his readers that Karlmann only turned to another woman because his legitimate wife was barren, he stresses that Arnulf's mother nevertheless had been a nobilis femina (and avoids giving her the negative epithet of "concubine«), he gives evidence of Arnulf's royal blood by describing him as unusually handsome, and he rationalizes his seemingly non-royal name by explaining that he had been named after Arnulf of Metz "from whose sainted line his own family and those of the other Frankish kings had sprouted forth « ${ }^{66}$ Regino then resolves this chequered marital history of Louis the German's descendants with the assertion that Louis the Child had been born to Arnulf "ex legitimo matrimonio. $"{ }^{67}$ This proclamation of Louis's legitimacy was a vital piece of Regino's argument, since Louis's mother Uota had in fact been accused of infidelity in the summer of 899, when her husband Arnulf was on his deathbed and Louis was six years old. Although Uota proved her innocence at an assembly in Regensburg with the support of seventy-two oath helpers, the charge of adultery nevertheless cast a potential shadow on Louis the Child's birth. ${ }^{68}$ Thus, Regino's explicit statements about legitimate marriage as well as his attempts to compensate for its absence demonstrate how much it mattered to him as a political category.

Regino's idealized picture of the East Frankish Carolingians and their marriages stands in sharp contrast to his depictions of other rulers. Scholars have long noted his detailed critique of Lothar II's marriage troubles. But what is often overlooked is Regino's sharp criticism of the West Frankish kings, as part of which he calls into question the legitimacy of their births. He is especially critical of the founder of the West Frankish kingdom Charles the Bald (840-877), who was Louis the German's younger half-brother. Regino stingingly accuses Charles the Bald of cowardice, greed, military incompetence, vainglory, and a disgraceful death, thereby making him the negative image of East Frankish royal virtue. ${ }^{69} \mathrm{He}$ also calls into question Charles's paternity when he blames the rebellions against Louis the Pious "on the manifold fornications of Judith his wife «, that is, Charles's mother. ${ }^{70}$ Regino likewise contrasts East Frankish royal beauty and physical strength with West Frankish bodily imperfections: one of Charles the Bald's sons has a speech impediment, a second suffers a crippling sword-slash to the face, and a third is blinded by his own father. ${ }^{71}$ Then, when

64 Regino, Chronicle, s.a. 876, ed. Kurze, 110-111; trans. MacLean, History and Politics, 174. Concerning Queen Emma, see Goldberg, Regina nitens.

65 Regino, Chronicle, s.a. 882 (Louis the Younger has a legitimate wife but their son dies from a tragic accident), 886 (justifies Charles the Fat's divorce on the grounds it had never been consummated), 890 (Arnulf's illegitimate son Zwentibald named after his godfather, the future king of Moravia and Bohemia), ed. Kurze, 118-119, 127, 134.

66 Regino, Chronicle, s.a. 880, ed. Kurze, 116; trans. MacLean, History and Politics, 182.

67 Regino, Chronicle, s.a. 900, ed. Kurze, 148.

68 Annales Fuldenses, s.a. 899, ed. Kurze, 132. Concerning the charges against Uota, see: Reuter, Sex; Dohmen, Ursache allen Übels, 288-311.

69 Regino, Chronicle, s.a. 860 (cowardice in battle), 873 (greed and ineffective leadership against Vikings), 876 (greed, fomenting civil war, ignominious defeat in battle), 877 (bribes pope, imperial vanity, cowardice, stench of corpse), ed. Kurze, 79, 106-107, 111-13.

70 Regino, Chronicle, s.a. 838, ed. Kurze, 74; trans. MacLean, History and Politics, 131.

71 Regino, Chronicle, s.a. 870, 878, ed. Kurze, 101-102, 114. 
Charles the Bald himself dies in Italy, his corpse gives off such an offensive stench that his companions become ill and are unable to bring the body back to Francia. ${ }^{72}$ Thus Regino's east Frankish Carolingians are physically beautiful and strong while their west Frankish relatives are defective and damaged.

On the surface, Regino's account of Charles the Bald's grandson, the current West Frankish king Charles the Simple, seems to offer neither praise nor censure. As we have already seen, caution probably explains his careful neutrality: although Lotharingia had been part of the East Frankish kingdom since 900, Charles the Simple had attempted to annex it in 898 and continued to have supporters in the region. ${ }^{73}$ But, beneath the surface, Regino undermines Charles the Simple's authority when he reports that his mother Adelheid had named her son after Charles the Bald, whom Charles the Simple as king did, in fact, consciously emulate. ${ }^{74}$ In light of his previous litany of criticism of Charles the Bald, Regino's comment serves as oblique condemnation of Charles the Simple, just as his acclaim for Louis the German serves as celebration for his namesake Louis the Child. Also, as we have seen, Regino throws doubt on the legitimacy of Charles the Simple's birth. He recounts how Charles's father Louis the Stammerer had been married once before as a young man and that that first marriage had produced Charles the Simple's older half-brothers, the West Frankish kings Louis III (879-882) and Carloman II (879-884). However, because Louis the Stammerer had married without his father's permission, Charles the Bald had forced him to separate and marry Charles the Simple's mother Adelheid, who was pregnant with Charles when Louis the Stammerer died. Regino does not explicitly pass judgment on whether this forced divorce and second marriage was canonical, but his praise for the beauty and valour of Louis III and Carloman II, and his refusal to attribute any royal virtue to Charles the Simple, implies that it was not. ${ }^{75}$ Regino further undermined Charles's legitimacy through his high praise for Charles's rival, the non-Carolingian usurper Odo (888-98), whom he describes as a handsome, manly, and skilled king. ${ }^{76}$ In this way, Regino wove throughout the second book of his Chronicle an implicit contrast between East Frankish dynastic virtue and legitimacy to which Louis the Child was heir, and West Frankish decline and possible illegitimacy represented by Charles the Simple.

Regino thus shaped his narrative about kingship and royal marriages in a way that made the case for Louis the Child as the chief rightful heir of the Carolingian line. For this reason, Regino did not offer an "objective « analysis of royal legitimacy based on the niceties of canon law, but instead a historical and political argument in favour of the East Frankish king. His stance tallies with arguments made in other texts written in circles around the young ruler. In letters written to the pope in 900, Archbishops Hatto of Mainz and Theotmar of Salzburg defended Louis the Child's legitimacy by underlining his descent from past Christian kings

Regino, Chronicle, s.a. 877, ed. Kurze, 113.

3 Regino, Chronicle, s.a. 898, ed. Kurze, 145-146.

74 Regino, Chronicle, s.a. 878, ed. Kurze, 114. For Charles the Simple's emulation of his grandfather, see Koziol, Politics of Memory, 544-548.

75 Regino, Chronicle, s.a. 878, 883, ed. Kurze, 114, 120.

76 Regino, Chronicle, s.a. 887, 888, 892, 893, ed. Kurze, 126-127, 129-130, 139-141. Regino's criticism of Charles might also explain his praise of the usurper Boso of Provence, the father of Charles's contemporary Louis the Blind: Regino, Chronicle, s.a. 879, ed. Kurze, 114-115. On Regino's positive portrayal of Odo, see also MacLean, Insinuation, 15-16. 
and emperors, and thus presented him as continuing the Carolingian line. ${ }^{77}$ A genealogy created during his reign (one of the earliest of its type) portrayed him in the same way. ${ }^{78} \mathrm{But}$ the dynastic history that Louis's apologists wished to claim was a contested one, as shown by a rival genealogy which presented Charles the Simple as the chief heir to Carolingian royal authority. ${ }^{79}$ Louis was not the only possible heir to the Carolingian past, and inconvenient facts such as Arnulf's illegitimacy and the rupture of 888 meant that the story could not be told without special pleading. The case had to be made, and Regino needed his expertise in both history and canon law to make it. He may have been hopeful that Louis represented the future for the Carolingians, but it was an optimism born of anxiety about the future rather than a sense of certainty about the past.

Undoubtedly, the need felt by Louis's supporters to shore up his legitimacy arose from his youth. He was the first fatherless child to become king in the Carolingian era, and others (including Charles the Simple in 888) had been excluded on those grounds in the recent past. The growing menace of Hungarian raiders in the 890 s and 900s made this a particular problem for the East Frankish kingdom. But with youth came another problem which must have troubled contemporaries but has barely been noticed by historians - should Louis marry, and if so whom? Without a wife, Louis remained a iuvenis, a youth, and thus not fully a man. With the East Frankish line bottle-necked to one young and yet unproven king, Louis's unmarried state must have worried anyone concerned with the future of the dynasty. A bride, followed by a legitimate heir, would give reassurance to the circles of aristocrats on whose support Louis (like any early medieval king) depended. Regino stood on the edge of those circles and sought to ingratiate himself with those closer to the centre. Significantly, in 908, the year that he sent his Chronicle to Adalbero, Louis turned 15 - the age of majority for Frankish males. Here was an opportunity for Regino to instruct and influence with his detailed knowledge of Frankish history - and at its centre, the history of good, bad and problematic marriages for the young king to emulate and avoid.

A number of other circumstances converged as Regino wrote his Chronicle that probably heightened his concerns about the young king's future marriage. One was the death of the previous queen, Louis's mother Uota. This seemingly happened in or shortly before March 907, when the king issued a charter redistributing some of her property to his sisters. ${ }^{80}$ Mothers of young kings not infrequently sought to defend their power by delaying their sons' marriages, so Uota's death just before her son came of age opened a space at court for a royal bride. Another charter from around the same period refers to Uota as "regina". This is significant as it was the first East Frankish royal charter to use that title for any royal woman. Regino's marital history was therefore written at a moment when East Frankish official discourse for the first time formally acknowledged the position of queen. ${ }^{81}$ 
907 brought a more dire crisis in the shape of the Battle of Bratislava (or Pressburg), one of the most calamitous defeats suffered by any army against the Hungarians. The defeated army was made up primarily of Bavarians, whose duke Liutpold, one of Louis's closest advisers, perished in the carnage. The shock of this military debacle almost certainly explains why Regino curtailed his narrative prematurely, in 906. The significant death toll among the magnates precipitated a major reorientation of the factions surrounding Louis. Influential families from the outlying regions of the kingdom lost ground - not least the decimated Bavarians - to the benefit of the already-powerful Conradines from Franconia. The leading member of this family, known as Conrad the Younger, now became particularly dominant. Among the closest allies of the Conradines were Hatto of Mainz and Adalbero of Augsburg, the bishops to whom Regino dedicated his canon law compilation and Chronicle. ${ }^{82}$ This further concentration of power around the Conradines, Hatto, and Adalbero ensured that they would strongly influence if, when, and whom the king would marry.

But what perhaps gave the question of Louis's marriage the most urgency was the marriage of Charles the Simple in April 907 to a woman named Frederun (d. 917). In 907 Charles was in his late 20 s and a self-conscious appropriator of Carolingian symbolism, and it is possible that his decision to marry at this point was calculated to pre-empt the impending majority of Louis the Child. He made an unusual effort to broadcast the significance of his new wife. In a diploma issued during an assembly at the venerable Carolingian palace of Attigny on 19 April 907, Charles gave Frederun a dower consisting of two royal palaces and bestowed upon her the honorific title of "consors regni« (partner in the kingdom) ${ }^{83} \mathrm{The}$ gift of royal palaces to a queen was virtually unprecedented, and the exalted epithet "consors regni« was an unusual honour in West Frankish politics. ${ }^{84}$ In a second charter, which records an assembly held a month later, Frederun performed her new status by appearing as petitioner for the bishop of Paris at the head of a list of the great and good of the realm. ${ }^{85}$ Frederun's political connections clearly enhanced Charles's enthusiasm for their marriage, although her exact family ties remain somewhat unclear. There is evidence that she had connections to the Saxon ducal family, known to history as the Liudolfings or Ottonians, and Charles later promoted Frederun's brother Bovo to the bishopric of Chalon-sur-Saône. Probably most significant is that Frederun seems to have come from Lotharingia. Evidence from later in Charles's reign strongly suggests that Frederun was closely associated with the powerful Matfriding family in that region. ${ }^{86}$

82 Hiestand, Pressburg 907; Offergeld, Reges pueri, 563-565, 612-619.

83 Lauer, Recueil, no. 56; MacLean, Ottonian Queenship, 41-42.

84 It had been used for Charles the Bald's queen in the 860s: Tessier, Recueil, nos. 269, 299; Erkens, Sicut Esther Regina, 22-36.

85 Lauer, Recueil, no. 57; Koziol, Politics of Memory, 517-524, 532, 546-548.

86 See Hlawitschka, Kontroverses; Gilsdorf, Queenship, 151-153; Depreux, Haganon, 384-389. Hlawitschka refutes the older argument that Frederun was a sister of the future Ottonain queen Mathilda. 
The Matfriding brothers Matfrid and Gerhard played a leading role in the tumultuous Lotharingian politics of the late ninth and early tenth centuries. Indeed, during the political crisis that attended Arnulf's death and Louis the Child's succession, Matfrid, Gerhard, and their accomplices (possibly with the connivance of the Conradines) had murdered Louis's elder half-brother, King Zwentibald of Lotharingia. ${ }^{87}$ At the same time, they ejected Regino himself from Prüm and installed their brother Richarius as abbot. ${ }^{88}$ Regino portrayed the Matfridings as betes noires in the Chronicle, which he concluded in 906 with a triumphant account of their defeat and public outlawry at an assembly held by Louis in Metz. ${ }^{89}$ For Regino, therefore, commitment to the future of Louis the Child's regime was not merely an abstract matter of loyalty to one's king or even of a principled interest in the continuation of the East Frankish Carolingians. Charles the Simple's marriage to Frederun was a menacing signal of his eastern ambitions and represented a threat not only to Louis, but to Regino personally. The marriage made the lack of a queen at Louis's court a potential point of urgency for those who, like Regino, were anxious about the future of Lotharingia and felt vulnerable to the insecurities of its aristocratic politics.

This, then, was the complex context surrounding Regino's dedication of his Chronicle to Adalbero of Augsburg in 907/908: the fall of the Matfridings (906), the death of Louis the Child's mother Uota (907), the marriage of Charles the Simple to Frederun (907), the crushing defeat of the Bavarian army at Bratislava (907), and Louis the Child's coming of age (908). These interconnected political events begged the question: would the East Frankish king marry? And, if so, whom? Although Regino does not explicitly address the question of Louis the Child's marriage, his high praise for his East Frankish ancestors - Louis the German, Karlmann, and Arnulf - strongly implied that the king needed to marry to continue the royal stirps blessed by Pope Stephen. His Chronicle thus offers an extended meditation on the nature of good and bad marriages, the perils of wicked queens and divorces, the troubles caused by illicit unions and illegitimate sons, and the generational challenges kings faced in producing adult male heirs acceptable to the magnates. It should be recalled that Regino at this time also dedicated his De synodalibus to Louis's other chief ecclesiastical counsellor, Hatto of Mainz, in which he presented the rules governing acceptable Christian marriages. In his eyes, therefore, history and canon law were intertwined, and both should serve as a guide for the selection of a bride for a young king. Regino highlights the urgency of heeding history and canon law in his Chronicle. In his very first entry on Lothar II's divorce, Regino reports that Lothar II "confessed that he could not long remain chaste and without marriage in the ardour of his youthful state " and that he had been disastrously counselled by a bishop "not particularly learned in divine scripture or trained in the canon law «.9 ${ }^{90}$ By dedicating his Chronicle and De synodalibus to Louis the Child's episcopal counsellors, Regino sought to ensure that a situation like this did not happen again.

87 Regino, Chronicle, s.a. 900, ed. Kurze, 148.

88 For an interpretation of these events with references to other literature, see MacLean, Insinuation.

89 Regino, Chronicle, s.a. 899, 900, 906, ed. Kurze, 147-148, 150-152.

90 Regino, Chronicle, s.a. 864, ed. Kurze, 81-82; trans. MacLean, History and Politics, 139. 
Perhaps the main reason Regino did not offer any overt suggestions about a potential wife for Louis was the fraught political dynamics of the moment. In light of the unrivalled pre-eminence of Conrad the Younger, a Conradine bride might seem like the obvious choice. But this would have been virtually impossible. References in royal charters imply that Louis's mother Uota had been a relative of Conrad the Younger, which would have made Louis's marriage to a Conradine uncanonical on the grounds of incest. ${ }^{91}$ Some scholars have even suggested Conrad the Younger sought to keep Louis single all along, since we know from hindsight that he became king when the still unmarried Louis died without heir in $911 . .^{92}$ While this is possible, it is far from certain, since no one could have known that Louis would die four years later at the age of eighteen. Another theoretical candidate for a bride would have been a daughter of the powerful Saxon-Thuringian duke Otto »the Illustrious« (d. 912), who was the brother of Louis the Younger's wife Liutgard and the father of King Henry I (919936). Otto seems to have had good relations with Conrad the Younger and Hatto of Mainz, and in 908 Louis issued a diploma at Otto's request that praised him as a vir venerabilis. ${ }^{93}$ Otto did in fact have three daughters, but all seem to have been ineligible: one (Oda) had been married to Louis's half-brother Zwentibald and was currently married to the Matfriding Gerhard; another (Liutgard) was a nun (she later became abbess of Gandersheim); and a third (unnamed) was illegitimate. ${ }^{94}$ These obstacles illustrate how the demands of dynastic politics and the constraints of canon law could be at odds with each other and significantly limit the pool of potential brides for an unmarried king. This may be another reason why Charles the Simple married Frederun in 907: to place this highly desirable bride with connections to Lotharingia beyond the reach of his eastern Carolingian rival. Regino of Prüm's Chronicle and De synodalibus, both of which he dedicated to Louis the Child's guardians, therefore highlight the tensions between the imperative that a king marry and produce a legitimate heir and the restrictions that canon law and aristocratic politics put on that imperative. No wonder Regino was worried. In the end, these tensions seem to have been insurmountable for the young king: when he died in 911, the East Frankish Carolingian line died with him. In the aftermath, Conrad the Younger became king of East Francia, and Charles the Simple finally took control of Lotharingia.

\section{Conclusion}

In discussing the history of royal marriage in Regino's Chronicle, we have not revealed any hidden subtext in the narrative. Rather, we have drawn attention to one of its most prominent themes - albeit one which is so obvious that it has been taken for granted in studies of the text. The Chronicle was of course not only a history of royal marriage, nor simply a set

91 Offergeld, Reges pueri, 566-569; Dohmen, Ursache allen Übels, 289-292.

92 Offergeld, Reges pueri, 615. See further Dümmler, Geschichte, vol. 3, 559-560 and n. 2.

93 Schieffer (ed.), Die Urkunden Ludwigs des Kindes, no. 63. Otto requested this charter (which gave free abbatial elections to the monastery of Hersfeld, where he was lay abbot) 'per supplicationem Hathonis illustris archiepiscopir. The fact that Hersfeld lay in Conrad's county and that Conrad later, as king, confirmed this grant implies that he supported Otto's request (see Schieffer's introduction to no. 63). Otto appears in a number of other diplomas of Louis the Child and Zwentibald: Schieffer (ed.), Die Urkunden Zwentibolds, nos. 19, 22; Schieffer (ed.), Die Urkunden Ludwigs des Kindes, nos. 15, 44. This evidence qualifies the argument of Offergeld, Reges pueri, 625-626, that the Saxons lost influence after Bratislava.

94 Gilsdorf, Queenship, xvi, 173. Regino, Chronicle, s.a. 897, 900, ed. Kurze, 145, 148, mentions Oda. 
of instructions for a king. Like many large-scale historical texts from the early Middle Ages, it was a project that spoke of its author's scholarship and piety, and one whose immediate audience was probably quite limited. But even if it gives us access to no more than the priorities and preoccupations of its author, that remains valuable because Regino himself was a political actor with close links to the royal court. Among its many complexities, the Chronicle can legitimately be read as Regino's response to the political context in which he wrote and dedicated it. The aim of this article has been to show that his approach to the history of the Frankish dynasties was shaped by his anxieties about the future of the Carolingians in East Francia, and the possible consequences for the fate of Lotharingia, in both of which Regino had a personal stake.

In expressing these anxieties through the writing of history, Regino did not offer any easy solutions - if anything, his concern was to show that there were no easy solutions. Partly, this was because of the constraints imposed upon him by the authority of the past. Although he edited his sources in line with what he saw as the best and most useful version of the past, and produced a text that he hoped was acceptable to the king's closest advisers, he seemingly did not feel at liberty flagrantly to alter what he read in the work of earlier historians. He regarded the $L H F$ and the others as sufficiently canonical and well-known that they could be manipulated only within limits. He could try to compensate for the crisis of 888 and the illegitimate birth of Arnulf, but he could not pretend that these historical problems did not exist. Where there were gaps in his knowledge (notably for the decades between the reigns of Charlemagne and Lothar II), he admitted as much rather than inventing or speculating. The culture of Carolingian history-writing transmitted structures of authority that still shaped the thinking of intellectuals like Regino even into the early tenth century.

Nonetheless, one of the things that makes Regino interesting is that he can be read as a rare example of an early medieval writer who was actually aware that he lived in an age of momentous transition. Many Frankish historians expressed anxiety about the future and held up golden ages of the past as mirrors to highlight the problems of the present, but Regino's perspective was more complex. The hope he invested in Louis the Child was set not only against the golden ages of Charlemagne and Louis the German, but also against the crisis of 888 that had seriously compromised the dominance of the Carolingian dynasty and inaugurated a period of disorder. Regino had not given up on the Carolingians, however, and he saw in Louis the Child an opportunity to restore the political order in East Francia and Lotharingia as it had existed before 888. But he seems to have held out no real hope of reuniting the empire as a whole, which demonstrates his understanding that things had fundamentally changed after the death of Charles the Fat. If they had not, why would he have needed to spend so much effort claiming that Louis was the natural heir of his dynasty's history? He acknowledged the paradigm shift of 888 , but he also hoped it was not definitive. In the end, though, Louis's early death rendered such hopes forlorn, and the era of dynastic uncertainty was prolonged. It would be nearly 30 years before an East Frankish king was again succeeded by his own son.

\section{Acknowledgements}

We thank Stuart Airlie for comments on an early version of this article; and acknowledge the support of the HERA JRP After Empire: Using and Not Using the Past in the Crisis of the Carolingian Empire. 


\section{References}

Abbreviations

MGH = Monumenta Germaniae Historica

MGH SRM = Scriptores rerum Merovingicarum

MGH SS = Monumenta Germaniae Historica, Scriptores

Airlie, Stuart, Private bodies and the body politic in the divorce case of Lothar II, Past and Present 161 (1998) 3-38.

Airlie, Stuart, "Sad stories of the deaths of kings«. Narrative patterns and structures of authority in Regino of Prüm's Chronicon, in: Elizabeth M. Tyler and Ross Balzaretti (eds.), Narrative and History in the Early Medieval West (Turnhout, 2006) 105-131.

Annales Bertiniani, ed. F. Grat, J. Vielliard, S. Clémencet and L. Levillain, Annales de Saint-Bertin (Paris, 1964).

Annales Fuldenses, ed. Friedrich Kurze, MGH SS rerum Germanicarum in usum scholarum 7 (Hanover, 1891).

Becher, Matthias, Arnulf von Kärnten - Name und Abstammung eines (illegitimen?) Karolingers, in: Uwe Ludwig (ed.), Nomen et fraternitas. Festschrift für Dieter Geuenich zum 65. Geburtstag (Berlin, 2008) 665-682.

Bede, De Temporum Ratione, ed. Charles W. Jones, Bedae opera didascalia 2, Corpus Christianorum Continuatio Medievalis 123B (Turnhout, 1977).

Beumann, Helmut, Die Einheit des ostfränkischen Reichs und der Kaisergedanke bei der Königserhebung Ludwigs des Kindes, Archiv für Diplomatik 23 (1977) 142-163.

Bishop, Jane, Bishops as marital advisers in the ninth century, in: Julius Kirshner and Suzanne F. Wemple (eds.), Women of the Medieval World (Oxford, 1985) 53-84.

Bohnenkamp, Lennart, Regino von Prüm und die religiöse Bedeutung der Geschichtsschreibung im Frühmittelalter, Concilium medii aevi 14 (2011) 289-317.

Bresslau, Harry, Der angebliche Brief des Erzbischofs Hatto von Mainz an Papst Johann IX., in: Historische Aufsätze. Karl Zeumer zum 60. Geburtstag als Festgabe dargebracht von Freunden und Schülern (Weimar, 1910) 9-30.

Brincken, Anna-Dorothee von den, Studien zur lateinischen Weltchronik bis in das Zeitalter Ottos von Freising (Dusseldorf, 1957).

Brühl, Carlrichard, Hinkmariana II. Hinkmar im Widerstreit von kanonischem Recht und Politik in Ehefragen, Deutsches Archiv 20 (1964) 48-77.

d'Avray, David, Medieval Marriage. Symbolism and Society (Oxford, 2005).

Depreux, Philippe, Le comte Haganon, favori de Charles le Simple, et l'aristocratie d'entre Loire et Rhin, in: Michèle Gaillard, Michel Margue, Alain Dierkens and Hérold Pettiau (eds.), De la mer du nord à la Méditerranée (Luxembourg, 2011) 381-394.

Deutinger, Roman, Königsherrschaft im Ostfränkischen Reich. Eine pragmatische Verfassungsgeschichte der späten Karolingerzeit (Ostfildern, 2006).

Dohmen, Linda, Die Ursache allen Übels. Untersuchungen zu den Unzuchtsvorwürfen gegen die Gemahlinnen der Karolinger (Ostfildern, 2017).

Dümmler, Ernst, Geschichte des ostfränkischen Reiches (Leipzig, 1886-1888).

Erkens, Franz-Reiner, Sicut Esther regina. Die westfränkische Königin als consors regni, Francia 20 (1993) 15-38. 
Gädecke, Nora, Eine Karolingergenealogie des frühen 10. Jahrhunderts?, Francia 15 (1987) 777-792.

Gesta Dagoberti, ed. Bruno Krusch, MGH SRM 2 (Hanover, 1888).

Gilsdorf, Sean, Queenship and Sanctity. The Lives of Mathilda and the Epitaph of Adelheid (Washington DC, 2004).

Goldberg, Eric J., Regina nitens sanctissima Hemma. Queen Emma (827-876), Bishop Witgar of Augsburg, and the Witgar-Belt, in: Simon MacLean and Björn Weiler (eds.), Representations of Power in Medieval Germany, 800-1500 (Turnhout, 2006), 57-95.

Goldberg, Eric J., Struggle for Empire. Kingship and Conflict under Louis the German, 817-876 (Ithaca, NY, 2006).

Halsall, Guy, Nero and Herod? The death of Chilperic and Gregory of Tours' writing of history, in: Kathleen Mitchell and Ian N. Wood (eds.), The World of Gregory of Tours (Leiden, 2002) 337-50.

Hartmann, Wilfried, Die Synoden der Karolingerzeit im Frankenreich und in Italien (Paderborn, 1989).

Haubrichs, Wolfgang, Die Kultur der Abtei Prüm zur Karolingerzeit (Bonn, 1979).

Heidecker, Karl, The Divorce of Lothar II. Christian Marriage and Political Power in the Carolingian World (Ithaca, NY, 2010).

Heidecker, Karl, Why should bishops be involved in marital affairs? Hincmar of Rheims on the divorce of King Lothar II (855-869), in: Joyce Hill and Mary Swan (eds.), The Community, the Family and the Saint. Patterns of Power in Early Medieval Europe (Turnhout, 1998) 225-235.

Hiestand, Rudolf, Pressburg 907. Eine Wende in der Geschichte des ostfränkischen Reiches?, Zeitschrift für Bayerische Landesgeschichte 57 (1994) 1-20.

Hlawitschka, Eduard, Kontroverses aus dem Umfeld von König Heinrichs I. Gemahlin Mathilde, in: Ernst-Dieter Hehl, Hubertus Seibert and Franz Staab (eds.), Deus qui mutat tempora. Menschen und Institutionen im Wandel des Mittelalters. Festschrift für Alfons Becker (Sigmaringen, 1987) 33-54.

Hlawitschka, Eduard, Regino von Prüm (gest. 915), Rheinische Lebensbilder 6 (1975) 7-27.

Hüschen, Heinrich, Regino von Prüm, Historiker, Kirchenrechtler und Musiktheoretiker, in: Heinrich Hüschen (ed.), Festschrift Karl Gustav Fellerer zum sechzigsten Geburtstag (Regensburg, 1962) 205-223.

Kottje, Raymund, Kirchliches Recht und Päpstlicher Autoritätsanspruch. Zu den Auseinandersetzungen über die Ehe Lothars II., in: Hubert Mordek (ed.), Aus Kirche und Reich. Festschrift für Friedrich Kempf (Sigmaringen, 1983) 97-103.

Koziol, Geoffrey, The Politics of Memory and Identity in Carolingian Royal Diplomas. The West Frankish Kingdom (840-987) (Turnhout, 2012).

Lauer, Philippe (ed.), Recueil des actes de Charles III le Simple, roi de France (893-923) (Paris, 1949).

Liber Historiae Francorum, ed. Bruno Krusch, MGH SRM 2 (Hanover, 1888).

MacLean, Simon, History and Politics in Late Carolingian and Ottonian Europe. The Chronicle of Regino of Prüm and Adalbert of Magdeburg (Manchester, 2009).

MacLean, Simon, Insinuation, censorship and the struggle for late Carolingian Lotharingia in Regino of Prüm's Chronicle, English Historical Review 124 (2009) 1-28.

MacLean, Simon, Kingship and Politics in the Late Ninth Century. Charles the Fat and the End of the Carolingian Empire (Cambridge, 2003).

MacLean, Simon, Ottonian Queenship (Oxford, 2017). 
McDougall, Sara, Royal Bastards. The Birth of Illegitimacy, 800-1230 (Oxford, 2017).

McKitterick, Rosamond, History and Memory in the Carolingian World (Cambridge, 2004).

McKitterick, Rosamond, Perceptions of the Past in the Early Middle Ages (Notre Dame, 2006).

McNamara, JoAnn and Suzanne F. Wemple, Marriage and divorce in the Frankish Kingdom, in: Susan Stuard (ed.), Women in Medieval Society (Philadelphia, 1976) 95-124.

Meens, Rob, The rise and fall of the Carolingians. Regino of Prüm and his conception of the Carolingian Empire, in: Laurent Jégou, Sylvie Joye, Thoms Leinhard and Jens Schneider (eds.), Faire lien. Aristocratie, réseaux et échanges compétitifs. Mélanges en l'honneur de Régine Le Jan (Paris, 2015) 315-324.

Offergeld, Thilo, Reges pueri. Das Königtum Minderjähriger im frühen Mittelalter (Hanover, 2001).

Regino of Prüm, Chronicon, ed. Friedrich Kurze, MGH SS rerum Germanicarum in usum scholarum 50 (Hanover, 1890).

Regino of Prüm, De synodalibus causis, ed. Wilfried Hartmann, Das Sendhandbuch des Regino von Prüm (Darmstadt, 2004).

Reimitz, Helmut, History, Frankish Identity and the Framing of Western Ethnicity, 550-850 (Cambridge, 2015).

Reuter, Timothy, Sex, lies and oath-helpers. The trial of Queen Uota, in: Timothy Reuter, Medieval Polities and Modern Mentalities (Cambridge, 2006) 217-230.

Reynolds, Philip, Marriage in the Western Church. The Christianization of Marriage during the Patristic and Early Medieval Periods (Leiden, 1994).

Schieffer, Theodor (ed.), Die Urkunden Zwentibolds und Ludwigs des Kindes (Berlin, 1960).

Schramm, Percy Ernst, Salbung und Krönung bei den Ostfranken bis zur Thronbesteigung König Heinrichs I., in: Kaiser, Könige und Päpste. Gesammelte Aufsätze zur Geschichte des Mittelalters 2 (Stuttgart, 1968) 287-302.

Sonntag, Regine, Studien zur Bewertung von Zahlenangaben in der Geschichtsschreibung des früheren Mittelalters. Die Decem libri historiarum Gregors von Tours und die Chronica Reginos von Prüm (Kallmunz, 1987).

Staubach, Nikolaus, Das Herrscherbild Karls des Kahlens. Formen und Funktionen monarchischer Repräsentation im früheren Mittelalter (Münster, 1981).

Stoclet, Alain, La »Clausula de unctione Pippini regis", vingt ans après, Revue belge de philologie et d'histoire 78 (2000) 719-771.

Tessier, Georges and Ferdinand Lot (eds.), Recueil des actes de Charles II le Chauve, roi de France (Paris, 1943-1955).

Toubert, Pierre, The Carolingian moment (Eighth-Tenth Century), in: Andre Burguière, Christiane Klapisch-Zuber, Martine Segalen and Francois Zonabend (eds.), A History of the Family 1 (Oxford, 1996) 379-406.

Ubl, Karl, Doppelmoral im karolingischen Kirchenrecht? Ehe und Inzest bei Regino von Prüm, in: Annette Grabowsky and Wilfried Hartmann (eds.), Recht und Gericht in Kirche und Welt um 900 (Munich, 2007) 91-124.

Ubl, Karl, Inzestverbot und Gesetzgebung. Die Konstruktion eines Verbrechens (300-110o) (Berlin, 2008).

West, Charles, Knowledge of the past and the judgement of history in tenth-century Trier. Regino of Prüm and the lost manuscript of Bishop Adventius of Metz, Early Medieval Europe 24 (2016) 137-159. 